\title{
TheEpistemic Communities as a Key to International Cooperation
}

\author{
Kristina Bekenova \\ College of Public Administration, Zhejiang University, P.R. China
}

\begin{abstract}
This research tests hypothesis - The epistemic communities play an important (key) role for international cooperation. The main question driving this study is to what extent was essential influence exerted by the Pugwash Conferences on Science and World Affairs on building interstate cooperation - between the USA and the USSR - in nuclear non-proliferation during the Cold War.The argument presented here is notwithstanding bipolar confrontation the USA-USSR cooperation in nuclear arms control issue thanks to the impact of the epistemic communities on politics of both countries was available.

This research uses case study method to examine several significant steps in nuclear cooperation between states: 1. How did become possible to sign the 1972 ABM Treaty by the Soviet Union and the United States?

2. What contribution did the epistemic community make to development of Nuclear Non-Proliferation Regime?

Putting together, conclusions of each of understudied cases let us to demonstrate the huge role played by communities in development international relations. The research concludes that in spite of the Cold War ideological frames deterred the USA-USSR cooperation, just with assistance of Pugwash scientific movement interstate collaboration in nuclear non-proliferation became available.
\end{abstract}

Keywords:epistemic communities, the Pugwash Conferences on Science and World Affairs, nuclear nonproliferation regime, the 1972 ABM Treaty

\section{Introduction}

On July 9, 1955, Bertrand Russell voiced the news of Albert Einstein's last public acts - a grave warning about the need to avoid war in the nuclear age. This Statement later was termed the Russell-Einstein Manifesto. In particular, the Manifesto suggests,

We have to learn to think in a new way. We have to learn to ask ourselves, not whatsteps can be taken to give military victory to whatever group we prefer, for there nolonger are such steps; the question we have to ask ourselves is what steps can be takento prevent a military contest of whichthe issue must be disastrous to all parties? ${ }^{1}$

In conclusion, it was proposed to assemble an international conference that would adopt the following resolution:

In view of the fact that in any future world war nuclear weapons will certainly beemployed, and that such weapons threaten the continued existence of mankind, weurge the governments of the world to realize, and to acknowledge publicly, that theirpurpose cannot be furthered by a world war, and we urge them, consequently, to findpeaceful means for the settlement of all matters of dispute between them ${ }^{2}$.

The Manifesto led directly to a conference of scientists, held in Pugwash, Nova Scotia in 1957.

This conference was a catalyst for a long-standing and fruitful dialogue of scientists from many countries on the most urgent problems of science and politics, developed into the formation of the transnational epistemic community - the Pugwash Conferences on Science and World Affairs. This organization has had a profound effect on developing superpower cooperation and formation of nuclear non-proliferation regime. In recognition of this important role, Pugwash and Joseph Rotblat, one of its key figures, were jointly awarded the 1995 Nobel Peace Prize for their "efforts to diminish the part played by nuclear arms in international affairs and, in the longer run, to eliminate such arms."

\footnotetext{
${ }^{1}$ Bertrand Russell, The Russell-Einstein Manifesto, July 9, 1955.The text of the Manifesto is from

http://www.pugwash.org/about/manifesto.htm

${ }^{2}$ Ibid.

${ }^{3}$ The Norwegian Nobel Committee, Nobel Peace Prize Announcement, 1995. The text of the Announcement is from http://www.pugwash.ru/history/documents1/394.html
} 
How did the Pugwash movement achieve such historic impact? What were the elements of its success, and are there lessons in this experience relevant to today's world?

\section{The Epistemic Communities}

The concept of "the epistemic communities" was introduced by Peter Haas. The epistemic community is represented the network of knowledge-based specialists, including scientists, politicians, government and public officials with different professional backgrounds, who, according to Peter Haas, "have shared intersubjective understandings; have a shared way of knowing; have shared patterns of reasoning; have a policy project drawing on shared values, shared causal beliefs, and the use of shared discursive practices; and have a shared commitment to the application and production of knowledge" 4 .

The epistemic communitiesexert a significant influence in multi-layered process. In Peter Haas's words, "the major dynamics are uncertainty, interpretation, and institutionalization" 5 . Particularly, in the period of uncertainty decision-makers ask the epistemic communities' members for advice because of their recognized expertize and competence can provide a framework for painstaking assessing the problem in order to understand and respond the issue.

The main event in the war history was the invention of atom bomb. The first and for the present the last use of nuclear weapon in war (on August 6, 1945 and on August 9, 1945 against the cities of Hiroshima and Nagasaki in Japan were conducted two atomic bombings by the United States) literally during one day changed the international situation. The implications for both national security and international system were unpredictable. Michael Brenner notes, that "The advent of nuclear weapons has had an unsettling effect on traditional notions of state interest and the enduring principles of military doctrine. Conventional ideas about the

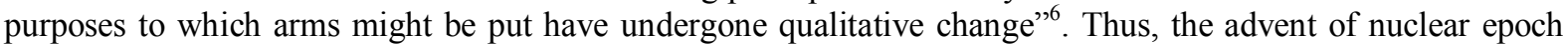
and atom bomb threat created the conditions of uncertainty, when never before the role of the epistemic communities has become so important.

The epistemic communities can provide the following knowledge-based help to decision-makers:

Epistemic communities can elucidate the cause-and-effect relationships andprovide advice about the likely results of various courses of action, ... canshed light on the nature of the complex interlinkages between issues and on thechain of events, ... can help define the selfinterests of a state or factions within it, ... can help formulate policies ${ }^{7}$.

So, it is important to highlight that epistemic communities called in the period of uncertainty can narrow the boundaries of doubtfulness, widen the boundaries of knowledge, and offer different kinds of decisions through "communication with leaders of states their theoretical understanding about the militarypolitical characteristics of nuclear weapons" $"$.

Epistemic communities, which can be presented both on the national and international levels, are significant actors in the decision-making process. Qualitative changes in international relations by confusing the relationship between foreign and domestic politics allow to Robert Putnam and Peter Gourevitch to talk about the entanglements of domestic and international politics. Robert Putnam writes,

A more adequate account of the domestic determinants of foreign policy and international relationsmust stress politics: parties, social classes, interest groups(both economic andnoneconomic),legislators, and even public opinion and elections, not simply executive officials and institutionalarrangements 9 .

In turn of Peter Gourevitch, he points international causes and domestic effects out. Writing about the transnational relations, modernization and interdependence school, he relying on Nye and Keohanestresses the growing role of transnational, international and multinational actors in shaping policy ${ }^{10}$.

\footnotetext{
${ }^{4}$ P. M. Haas, "Introduction: Epistemic Communities and International Policy Coordination”, International Organization 46, no. 1 (1992), p. 3 ${ }^{5}$ Ibid.

${ }^{6}$ M. J. Brenner, "The Theorist as Actor, the Actor as Theorist: Strategy in the Nixon Administration", Stanford Journal of International Studies 7 (Spring, 1972), p. 110

${ }^{7}$ P. M. Haas, "Introduction",p. 15

${ }^{8}$ M. J. Brenner, "The Theorist as Actor, the Actor as Theories", p. 109

${ }^{9}$ R. D. Putnam, "Diplomacy and Domestic Politics: The Logic of Two-Level Games", International Organization 42, no. 3 (1988), p. 432

${ }^{10}$ P. Gourevitch, "The Second Image Reversed: The International Sources of Domestic Politics", International Organization 32, no. 4 (1978), p. 893
} 
So, national epistemic communities as national group of professionals can exert every effort (knowledge, activities) toward a single country, as was described by Emanuel Adler in the case of the USA ${ }^{11}$. But "collaboration in the absence of material interests binding together actors in different countries with common policy agendas would strongly suggest the existence of an epistemic community with transnational membership", and "because of its larger diffusion network, a transnational community's influence is likely to be much more sustained and intense than that of a national community"12.

Thus, it is worth to define the epistemic communities as transnational actors, based on the Thomas Risse-Kapan's definition of transnational relations, i.e., "regular interactions across national boundaries when at least one actor is a non-state agent or does not operate on behalf of a national government or an intergovernmental organization" ${ }^{13}$. And taking in account the USA as one of the "democratic polities" which"permit penetration of government policy-making by transnational as well as domestic actors", and the Soviet Union with "the centralized, secretive, and authoritarian regime prevaileduntil the end of the $1980 \mathrm{~s}$ "14, this research analyzes why it was possible by the Pugwash movement to be like a partner of both the East and the West.

\section{The Pugwash Conferences On Science And World Affairs}

The Pugwash epistemic community played a key role in creating the international shared understanding and practice of nuclear non-proliferation, which made favorable settings for cooperation between superpowers during the Cold War. In this study, I analyze how the community's theoretical and practical ideas became political decisions, were diffused to the Soviet Union and the USA, and were ultimately embodied in the nuclear non-proliferation regime.

\subsection{The Pugwash Community's Principled Beliefs}

The Pugwash movement has become the result of the efforts by scientists in the 1950s in order to focus world attention on the critical need for new approaches to international security in the nuclear age. In particular, scientists were not sure that national leaders and the public completely understood the implications of the new and devastating hydrogen bombs.Russel in his letter to Einstein wrote, "I think the next step should be an international scientific congress... I hope thatin this way both governments and public opinion can be made aware of the seriousnessof the situation" 15 .The importance and authoritativeness of the Pugwash, its huge international impact, and its success in achieving nuclear issue goals, are explained by principles underlying in the community.

Firstis the highest scientific repute of the Pugwash members represented moral and intellectual authority. The participation of 9 signatories of the Russell-Einstein Manifesto, who represent collection of a considerable number of Nobel Laureates in physics and chemistry ( 9 of 11 signatories of the Russell-Einstein Manifesto are Nobel Laureates in physics and chemistry), provided a fertile ground for involving another scientists and specialists. In addition, scientists feel "a special responsibility, sincetheir work has unintentionally caused our present dangers"16. Some of the Pugwash members took participation in Manhattan project (The Manhattan Project, began in 1939, was a research and development program led by the United States with participation from the United Kingdom and Canada that produced the first atomic bomb during World War II), like Leo Szilard, Rudolf Ernst Peierls, Samuel King Allison.

Second is the meeting in private as individuals, rather than as representatives of governments or institutions. This mode of meetings allow to "Pugwash participants exchange views and explore alternative approaches to arms control and tension reduction with a combination of candor, continuity, and flexibility seldom attained in official East-West and North-South discussions and negotiations" ${ }^{\text {"17 }}$."These men [members of Pugwash] should be so diverse in their politics that any statement signed by all of them would be obviously free from pro-Communist or anti-Communist bias". ${ }^{18}$ Bertrand Russellsuggested that "a meeting between Western

\footnotetext{
${ }^{11}$ E. Adler, "The Emergence of Cooperation: National Epistemic Communities and the International Evolution of the Idea of Nuclear Arms Control", International Organization 46, no. 1 (1992), pp. 101-145

${ }^{12}$ P. M. Haas, "Introduction", p. 17

${ }^{13}$ Thomas Risse-Kappen, "Bringing Transnational Relations Back In: Introduction", in Bringing Transnational Relations Back In: Non-State Actors, Domestic Structures, and International Institutions, ed. Thomas Risse-Kappen (Cambridge, MA: Cambridge University Press, 1995), p. 3

${ }^{4}$ Matthew Evangelista, “Transnational Relations, Domestic Structures, and Security Policy in the USSR and Russia”, in Bringing

Transnational Relations Back In: Non-State Actors, Domestic Structures, and International Institutions, ed. Thomas Risse-Kappen (Cambridge University Press, 1995), pp. 146-147

${ }^{15}$ Sandra I. Butcher, "The Origins of the Russell-Einstein Manifesto", Pugwash History Series 1 (May 2005), p. 14

${ }^{16}$ Sandra I. Butcher, "The Origins of the Russell-Einstein Manifesto", p. 14

17 About Pugwash, the Pugwash Conferences on Science and World Affairs, last modified December 19 , 2011. http://www.pugwash.org/about.htm

${ }^{18}$ Sandra I. Butcher, "The Origins of the Russell-Einstein Manifesto", p. 12
} 
and Soviet scientists might provide the best entry towards genuine co-operation and establishment of a system of international control". 19

Third, all members of the Pugwash have the intersubjective understanding about nuclear threat. "Mankind is faced with a clear-cut alternative: either we shall all perish, or we shall have to acquire some slight degree of common sense. A great deal of new political thinking will be necessary if utter disaster is to be averted" 20 . Members of this community knew each other well: "they knew one another, either personally or through their scientific publications, and they had respect to one another's scientific integrity" ${ }^{21}$. Thus, they learned from one another and together generated new ideas.

So, because of their political and ideological non-attachment, the very highest competence in understudied issues, the epistemic community members "use their scientific prestige to gain legitimacy and authority within the political system"22. Notwithstanding they represent one community, but the same time they were everywhere: they were members of government bureaus, research organizations and laboratories, profit and nonprofit organizations, university research centers, and think tanks. Such involvement in different spheres was significant, because "their effectiveness depended on their relative autonomy from political power, their ability to keep separate from current critical pressures, to retain their scientific integrity and authority, and to continue to innovate" ${ }^{23}$. So, using diverse channels to spread their nuclear non-proliferation ideas, their international impact has become fundamental.

\subsection{The USA-USSR Cooperation}

Beginning in 1957, the Pugwash meetings that brought together Western and East European scientists to discuss the threat posed to civilization by the advent of nuclear weapon played an essential role in overcoming mutual misperceptions between western and non-western intellectuals, in creating favorable conditions for the USA-USSR cooperation resulted in the 1972 Anti-Ballistic Missile Treaty (ABM Treaty). According to J. Rotblat,

In many instances the scientists from the West received, for the first time,reasoned objections to their views from scientists in the East and vice-versa. This confrontation of ideas, of prejudices, and of causes of mistrust, was in itselfvery valuable, as it gave an opportunity for better understandingof the motivationof others and, in some cases, removed misunderstandings and dispelled fears ${ }^{24}$.

So, if we talk about the importance of Pugwash as a channel of communication between West and East, and the importance of Pugwash as a confident basis for changing ideas, in this sense how did such structure of Pugwash lead to result?

The 1972 ABM Treaty is an example of the key role and huge impact of Pugwash Conferences on Science and World Affairs on foreign policies of both Soviet Union and United States. Metta Spencer wrote in the July/August 1995 Bulletin of the Atomic Scientists, "Pugwash played pivotal but behind-the-scenes role in influencing the political leaders of the superpowers" 25 .

Before the case study it is necessary to introduce two eminent Soviet nuclear physicists who made especially important contributions in moderating their nation's engagement in the nuclear arms race. Mikhail Millionshchikov was vice president of the Soviet Academy of Science, and Lev Artsimovichwas in charge of the Soviet fusion research program.

Well, in Spencer's article, she examines the contribution of Pugwash in preventing of nuclear arms race. In particularly she writes, that in 1960s the Soviet Union on the governmental level did not want to understand that defensive weapons in nuclear era were destabilizing. At a 1964 Pugwash Conference in India, Millionshchikov protected the Soviet position talked about why the Soviet Union should develop these defenses. Professor of Massachusetts Institute of TechnologyJack Ruina made very strong counter-arguments, but anyway "nobody believed his [Millionshchikov's] thinking had been changed"26.

When Pugwash met the following year the topic came up again, and this time Millionshchikov came back asking for more details. "It was clear to us that he had presented his views to the government and the generals back there and they again came out asking for more details: In what way would such a development

\footnotetext{
${ }^{19}$ Ibid., p. 7

${ }^{20}$ Ibid, p. 6

${ }^{21}$ Mike Moore, "Forty Years of Pugwash", The Bulletin of the Atomic Scientists 53,no. 6 (November, 1997), p. 41

${ }^{22}$ E. Adler, "The Emergence of Cooperation", p. 112

${ }^{23}$ Ibid., pp. 112-113

${ }^{24}$ Ibid., pp. 121-122

${ }^{25}$ Metta Spencer, “'Political' Scientists”, The Bulletin of the Atomic Scientists 51, no. 4 (July/August, 1995), p. 62

${ }^{26}$ Ibid., p. 64
} 
affect the future arms race? It was clear to us that he wanted to be armed with such arguments that he could present back on the other side",27.

Then, on the 1969 Sochi Conference, Millionshchikov definitely opposed ABM-systems. The statement was:

Deployment of either of these weapon systems will not only increase the waste of resources and the danger of accidental or unauthorized launching of nuclear-armed missiles but will also increase the probability of nuclear war, since one or the other major nuclear powers might conclude that there are advantages to be gained by striking first rather than accepting the risk of a first blow by its adversary ${ }^{28}$.

A month after the Pugwash meeting in Sochi, the Strategic Arms Limitation Talks began in Helsinki. One outcome was the ABM Treaty of 1972, which successfully prevented a destabilizing race for defenses against ballistic missiles.

So, why did the Soviet government abandon its simplistic position that "defense is moral; offense is immoral"29? First of all, it will be useful to understand the changing in Millionshchikov's mind, then, to see the impact of the Pugwash ideas to the Soviet government.

Millionshchikov wrote, that "The participants during the 1964 Pugwash meeting had learned much from each other... I had privately come around to the anti-ABM position in 1964" 30 .Understood the interconnection between offensive and defensive weapons, Artsimovichopenly stated his concerns about AntiBallistic Missilesat the 1967 Pugwash conference ${ }^{31}$.

Next step is concentrated on domestic structure of the Soviet Union. As Matthew Evangelista concludes,

Certain aspects of the domestic structure of the Soviet Union - in particular thedomination of a weak, fragmented society by a strong hierarchical party-state apparatus - made it difficult for new ideas to find their way to the top of the policyprocess. Once a window of opportunity provided policy entrepreneurs with access tothe leadership, however, they were often able to see theirideas implemented quickly. In the security field such policy entrepreneurs were typically members of transnationalorganizations - most notably the Pugwash Conference of Scientists - and many their ideas came from international discussions ${ }^{32}$.

And that's why both Millionshchikov who was a chairman of the Supreme Soviet of the Russian Federative Republic, and academician Vladimir Kirillin who was Vice Prime Minister of the USSR and Chairman of the State Committee on Science and Techniques under the USSR Council of Ministers had such significant impact on both First Secretary Leonid Brezhnev and on Soviet Premier Kosygin.

So, thanks to joint efforts of Western and Eastern scientists united by the Pugwash transnational epistemic community the USA and the USSR succeeded in signing the 1972 ABM Treaty. As Bernd Kubbig, professor of the Peace Research Institute in Frankfurt, Germany, notes, "Pugwash was instrumental in bringing Soviet policy-makers around to the idea that nuclear-armed nations should cooperate in achieving strategic stability, an insight that undergirds the 1972 ABM treaty as well as all subsequent strategic arms treaties"33. And the main value of these discussions is that the participants who played a key role in American or Soviet administrationduring their Pugwash meetings could freely and openly discuss international security issues, and then they came back from such meetings with understanding that notwithstanding the Cold War superpowers confrontation, the states wanted cooperate with each other.

\section{Toward A Nuclear Non-Proliferation Regime}

The Nuclear non-proliferation regime, according to John Simpson's apt expression, represents "the patchwork of treaties, political agreements and understandings designed to prevent nuclear proliferation" ${ }^{\text {, }}$. Based on the 1968 Non-Proliferation of Nuclear Weapons Treaty NPT), the nuclear non-proliferation regime

\footnotetext{
27 Ibid.

28 Ibid.

${ }^{29}$ Such position was voiced by Soviet Premier Alexei Kosygin at the June 1967 Summit in Glassboro, New Jersey, in the respond to McNamara who told to Premier that no matter how strong Soviet defense were, the US would build the weapons necessary to overcome them. See Metta Spencer, 'Political' Scientists, p. 64

${ }^{30}$ E. Grigoluk, "Time, Ideas, Destinies", Herald of The Russian Academic of Science 3 (1998), p. 267

${ }^{31}$ Ibid.

${ }^{32}$ Matthew Evangelista, “Transnational Relations, Domestic Structures", p.147

${ }^{33}$ Mike Moore, "Forty Years of Pugwash", p. 42

${ }^{34}$ John Simpson, "The Nuclear Non-Proliferation Regime: Back to the Future?" UNIDIR Web, http://unidir.org/pdf/articles/pdf-art2015.pdf
}

www.iosrjournals.org $72 \mid$ Page


includes "unilateral constraints; bilateral agreements between the United States and the Soviet Union; multilateral non-proliferation and disarmament agreements; and multilateral guidelines on national legislation to deny transfers of relevant materials and technology to suspected proliferators ${ }^{\text {"35. }}$.

This chapter aims to contribute to our understanding of the impact of the Pugwash Conference of Science and World Affairs on giving rise to nuclear non-proliferation regime. How was it become possible to establish this regime during the Cold War?

There are theoretical applications concerned on what is international regime, what conditions are necessary to achieve international regime, and what features do have security regimes in the first section. Then, in the second section, by author is examined to what extent was a key role of the Pugwash participants in creating of understanding between the states for establishing such regime.

\subsection{International Regime}

According Stephen Krasner, "Regimes can be defined as sets of implicit or explicit principles, norms, rules, and decision-making procedures around which actors' expectations converge in a given area of international relations ${ }^{\prime 36}$.Jervis notes, that the concept of regimes "implies not only norms and expectations that facilitate cooperation, but a form of cooperation that is more than the following of short-run self-interest ${ }^{37}$. In these definitions the following points should be emphasized.

First, rules represented by "specific prescriptions or proscriptions for action"38 are at stake. These rules determine states' behavior.Second, restrictive conditions are at stake. Voluntary acceptance of regime commitments must be answered the state's long-termed interest ${ }^{39}$.Third, the acceptance of reciprocity of states means that "they willsacrifice short-term interests with the expectation that other actors will reciprocatein the future, even if they are not under a specific obligation to doso" ${ }^{\circ 0}$.

So, taking into account above-mentioned features of international regime, Jervis claims that "Security regimes are thus both especially valuable and especially difficult to achieve"41. But in the same time "statesmen usually think they should "play it safe" by building positions of greater strength... The result isthat security regimes, with their call for mutual restraint and limitations onunilateral actions, rarely seem attractive to decision makers, ${ }^{42}$.

Then, explaining the possibility to form and maintain a security regime, Jervis introduces the following "most propitious" conditions: the states' desire to establish it, shared values and beliefs among the states, the states' understanding of cooperation as the more desirable benefit, and pursuance of war must be seen as costly ${ }^{43}$.

Thus, became familiar with theoretical background, the next step is examining the impact of the Pugwash movement on formation a nuclear non-proliferation regime.

\subsection{The Pugwash Efforts}

For the sake of consistency and clarity, it is worth to summarize this paper's findings and arguments utilizing them to examine the role of Pugwashites to develop the nuclear non-proliferation regime.

\section{Who constitutes the community?}

The Pugwash epistemic community was a direct outcome of a paper issued in 1955 by Bertrand Russell and Albert Einstein. The 1957 meeting was attended by 22 eminent scientists (seven from the United States, three each from the Soviet Union and Japan, two each from the United Kingdom and Canada, and one each from Australia, Austria, China, France, and Poland). In the following meetings, as participants have become not only scientists, but also members of the general public, politicians, knowledge-based specialists, and governmental officials. The Pugwashites have professional and personal ties with state administration officials.

\section{What are the community's principled beliefs? What policy prescriptions does the community propose?}

On the level of scientific beliefs, it was self-evident that impartial and non-partisan scientific analysis of political problems could be beneficial to policy-makers, and that openness and information sharing were critically important to achieve a fruitful and positive way which helped foster trust and mutual understanding,

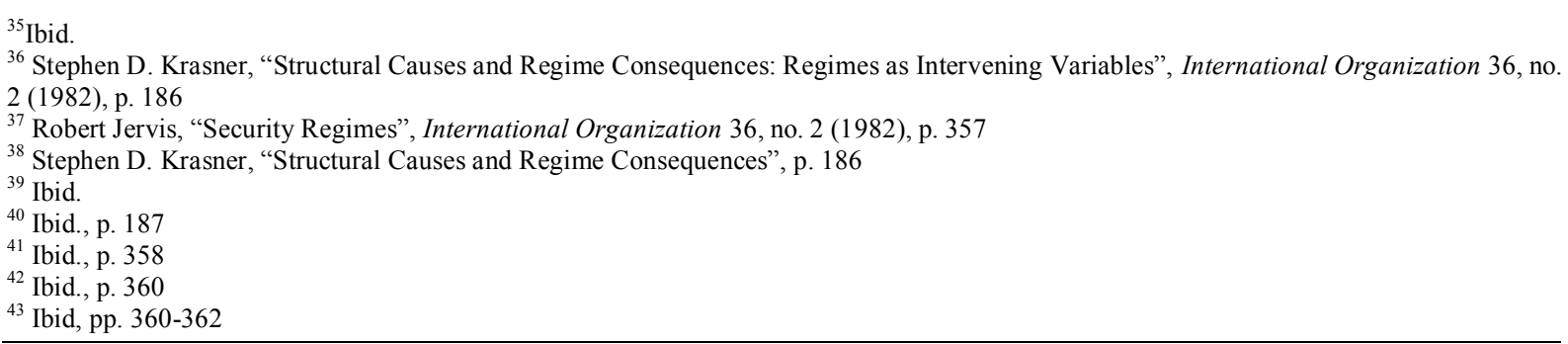


and to resolve political issues. Pugwash meetings remarked on the like-mindedness, even unanimity, among those who studied the problem of nuclear non-proliferation. Such construction of meetings gave rise to the general policy prescription of non-proliferation. Pugwashites believe that only through concerted international efforts, and through exchange of scientific information an adequate openness and sharing of research could be obtained. The community's core beliefs become so normalized and so widely accepted that they found vent in the 1968 NPT (to date, a total of 190 states have joined the Treaty).

What is the policy question in the period of uncertainty? What aspects are understood as uncertainty?

The core area of uncertainty, created by the advent of atomic bomb, affects the security of the international system as whole. The particular policy questions varied,first of all, according to unfolded events varied. By Pugwash conference were examined the following issues: nuclear disarmament and international security (1960-1965), scientific and technical cooperation as investment to international cooperation (1968, 1969,1972 , and 1975), energy issues $(1969,1974)$, etc.

\section{At what stage in the decision-making process is community advice sought? What are formal and informal access} channels?

Community members were called upon to advice on issues of central importance, the answers to which were far from clear. In the majority of cases, community members were brought in early in the process, they can moderate policy prescriptions. Access was generally formal, through reports and writings addressed to the appropriate officials. Also, the community's members have professional and personal ties with state administration officials. As Jean-Jacques Salomon notes: "A reading of the lists of participants in the Pugwash conferences is enough to pick out the names of the scientists or political observers who are officially or unofficially linked with political decision-making bodies whether in the East or West" ${ }^{\prime 4}$.

So, Pugwash expertise and analysis were instrumental in demonstrating the destabilizing effects of using nuclear weapons, which led to the 1963 Partial-Test Ban Treaty, the 1968 NPT, the 1970 Nuclear Nonproliferation Treaty, the 1972 Biological Weapons Ban, thefirst Strategic Arms Limitations Talk (SALT I), including the ban on anti-ballistic missiles in 1972, and SALT II in 1978 - all stand as milestones to way toward nuclear non-proliferation regime.

The importance of Pugwash meetings consists precisely in the fact that "a dialogue takes place there between people who know the problems well and who can unofficially inform those government bodies which deal with these problems through state-to-state channels" ${ }^{\$ 5}$. Since 1950 s, the eminent scientists, knowledgebased specialists have been forming networks to promote ideas and policies that lessen the danger of nuclear weapons.

Establishing of such regime became possible through "communicative action" ${ }^{46}$ of the Pugwash community. Emanuel Adler, Peter M. Haas writes,

As Judith Innis points out, the key idea in this regard is that communication and action "are so closely intermeshed that they cannot be conceptually distinguished" and that the negotiations of meanings, understandings, and beliefs are intertwinedwith the negotiations of actions at everystep along the way... Epistemic communitiescontribute both to the transparency of actionsand tothe stable expectations of others'behavior. Such common inferences can inturn contribute to cooperation even withoutformal organizations ${ }^{47}$.

Thus, the Pugwash meetings, gave the opportunity to ideas exchange and to discuss issues openly, promoted in the first instance to understand among scientists, and then among states' officials that notwithstanding being a part of one or another ideological camps the states seek international stability and security through cooperation in "especially valuable and especially difficult to achieve" sphere as nonproliferation of nuclear weapons.

\section{Conclusion}

The Pugwash Conference on Science and World Affairs has become "a truly international conference, organized by scientists, with participants from East and West, was convened not to discuss specific technical matters, but

\footnotetext{
${ }^{44}$ Eugene Garffeid, ed., The Pugwash Conferences on Science and World Affairs: Twenty-two Years in Search of Peace, vol. 4 of Essays of an Information Scientist (Philadelphia, PA: ISI Press, 1981), p. 205

${ }^{45}$ Matthew Evangelista, Unarmed Forces: The Transnational Movement to End the Cold War (Ithaca, NY: Cornell University Press, 2002), p. 146

${ }^{46}$ E. Adler, P. M. Haas, "Conclusion: Epistemic Communities, World Order, and the Creation of a Reflective Research Program",

International Organization 46, no. 1, p. 389

${ }^{47}$ E. Adler, P. M. Haas, "Conclusion”, p. 389
} 
the social implications of scientific discovery" ${ }^{48}$ Called upon for advice under conditions of uncertainty, then this epistemic community has become a key actor to international cooperation. Pugwash meetings made possible cooperation between the USA and the USSR in such vulnerable sphere as security. The Pugwash community being like guidance on nuclear issues could persuade the state to establish nuclear non-proliferation regime as an essential condition of international peace and world security.

So, on the case of Pugwash, was demonstrated how an epistemic community with the highest repute and competence community membership, shared principled and causal beliefscan influence on decision makers through identifying alternative beneficial foreign policy outcomes.

Considering about epistemic community as transnational actor, when "science knows no national boundaries"49, we can even talk about environmental, human rights, or economic epistemic communities, which can cooperate with wonderful and historic effect.Who knows, maybe the words of Winston Churchill "The empires of the future are the empires of the mind" are prophetic?

\section{References}

[1] B. Russell.The Russell-Einstein Manifesto, July 9, 1955.The text of the Manifesto is from http://www.pugwash.org/about/manifesto.htm

[2] The Norwegian Nobel Committee. Nobel Peace Prize Announcement, 1995. The text of the Announcement is from http://www.pugwash.ru/history/documents1/394.html

[3] P. M. Haas. "Introduction: Epistemic Communities and International Policy Coordination". International Organization 46, no. 1 (1992), 1-35.

[4] M. J. Brenner. "The Theorist as Actor, the Actor as Theorist: Strategy in the Nixon Administration".Stanford Journal of International Studies 7 (Spring, 1972), 109-131.

[5] R.D. Putnam. "Diplomacy and Domestic Politics: The Logic of Two-Level Games." International Organization 42, no. 3 (1988), 427-460.

[6] P. Gourevitch. "The Second Image Reversed: The International Sources of Domestic Politics." International Organization 32, no. 4 (1978), 881-912.

[7] E. Adler. "The Emergence of Cooperation: National Epistemic Communities and the International Evolution of the Idea of Nuclear Arms Control." International Organization 46, no. 1 (1992), 101-145.

[8] T. Risse-Kappen. "Bringing Transnational Relations Back In: Introduction." In Bringing Transnational Relations Back In: NonState Actors, Domestic Structures, and International Institutions, edited by Thomas Risse-Kappen, 3-34. Cambridge, MA: Cambridge University Press, 1995.

[9] M. Evangelista. "Transnational Relations, Domestic Structures, and Security Policy in the USSR and Russia." In Bringing Transnational Relations Back In: Non-State Actors, Domestic Structures, and International Institutions, edited by Thomas RisseKappen, 146-188. Cambridge, MA: Cambridge University Press, 1995.

[10] S.I. Buftcher. "The Origins of the Russell-Einstein Manifesto."Pugwash History Series 1 (May 2005), 7-35.

[11] "About Pugwash", The Pugwash Conferences on Science and World Affairs, last modified December $19,2011$. http://www.pugwash.org/about.htm

[12] M. Moore. "Forty Years of Pugwash." The Bulletin of the Atomic Scientists 53, no. 6 (November, 1997), 40-45.

[13] M. Spencer." 'Political' Scientists”.The Bulletin of the Atomic Scientists 51, no. 4 (July/August, 1995), 62-68.

[14] E. Grigoluk. "Time, Ideas, Destinies.” Herald of the Russian Academic of Science 3 (1998), 266-268.

[15] J. Simpson. "The Nuclear Non-Proliferation Regime: Back to the Future?" UNIDIR Web, http://unidir.org/pdf/articles/pdfart2015.pdf

[16] S. D. Krasner. "Structural Causes and Regime Consequences: Regimes as Intervening Variables". International Organization 36, no. 2 (1982), 185-205.

[17] R. Jervis. "Security Regimes".International Organization 36, no. 2 (1982), 357-378.

[18] E. Garffeid. The Pugwash Conferences on Science and World Affairs: Twenty-two Years in Search of Peace, vol. 4 of Essays of an Information Scientist. Philadelphia, PA: ISI Press, 1981.

[19] M. Evangelista. Unarmed Forces: The Transnational Movement to End the Cold War. Ithaca, NY: Cornell University Press, 2002.

[20] E. Adler, P. M. Haas."Conclusion: Epistemic Communities, World Order, and the Creation of a Reflective Research Program”.International Organization 46, no. 1, 367-390.

\footnotetext{
${ }^{48}$ Eugene Garffeid, ed., The Pugwash Conferences on Science and World Affairs, p. 201

${ }^{49}$ Metta Spencer, “'Political' Scientists”, p. 62
} 